\title{
THE SERPVAL SCALE: \\ A MULTI-ITEM SCALE FOR MEASURING SERVICE PERSONAL VALUES *
}

\author{
Joana Cosme Fernandes** \\ and \\ Luis Filipe Lages***
}

Working Paper nr. 423, ISSN 0871-2573

Universidade Nova de Lisboa, Faculdade de Economia

December, 2002

* This research was funded by a research grant from NOVA EGIDE to the second author. The
authors would like to thank Reinaldo Proenca, James Harris, Helena Goncalves, and John
Huffstot for comments on earlier versions of the manuscript.
** Joana Cosme Fernandes is Business Controller at Ericsson Telecommunications Portugal,
Edifício D. Henrique, Quinta da Fonte, 2780-730 Paço de Arcos, Portugal. Phone: ++
351.21.4466.662, fax: ++ 351.21.4466.680, joana.fernandes @ sep.ericsson.se
*** Luis Filipe Lages is Assistant Professor of Marketing and International Business at
Universidade Nova de Lisboa, Faculdade de Economia, Campus de Campolide, 1099-032
Lisboa, Portugal. Phone: ++ 351.21.3801.600, fax: ++ 351.21.3886.073, lflages@fe.unl.pt,
www.fe.unl.pt/ lflages 


\begin{abstract}
ABOUT THE AUTHORS
Joana Cosme Fernandes is Business Controller at Ericsson Telecommunications, Portugal. Her research in the field of services marketing has been published in several international conference proceedings. e-mail: joana.fernandes@ sep.ericsson.se

Luis Filipe Lages is Assistant Professor of Marketing and International Business at Universidade Nova de Lisboa (UNL), Faculdade de Economia, Portugal. Previously, he was a Visiting Scholar at Stanford University, Graduate School of Business and at MIT, Sloan School of Management. He received his $\mathrm{PhD}$ in Marketing and Strategic Management from Warwick Business School, Warwick University, U.K. His research in the field of marketing and international business has been published in several journals as well as in numerous international conference proceedings. e-mail: lflages@fe.unl.pt url: http://www.fe.unl.pt/ lflages
\end{abstract}




\title{
THE SERPVAL SCALE:
}

\section{A MULTI-ITEM SCALE FOR MEASURING SERVICE PERSONAL VALUES}

\begin{abstract}
Personal values have long been considered an important variable in understanding consumer purchasing behaviors. Although research on values has been performed in a wide range of social disciplines, this variable has never been operationalized in the service management context. In this paper we develop a scale that measures the personal values that are associated with buying a service: the Service Personal Values (SERPVAL) scale. Insights from an empirical study of 386 service users indicate that this scale is multi-dimensional. It presents four dimensions of service value to 1) living comfort, 2) peaceful life, 3) social recognition, and 4) social integration. Discussion centers on implications of this scale to theory and to managerial development of services strategies. Directions for future research in services management and personal values are also presented.
\end{abstract}

Keywords: Services Management, Services Marketing, Personal Values, Measurement, SERPVALScale 


\section{INTRODUCTION}

The shift towards a service-based economy has been globally evident since the 1970s. Since then growth has proceeded at double-digit rates. Today, services are a global business with the value of global trade representing one fifth of all world trade. Even though services are growing at an ever-faster pace, literature has focused on a limited number of aspects, considering mainly the extent to which consumers recognize service quality (Parasuraman, Zeithaml, \& Berry, 1985, 1988, 1991, 1994) or service value (Bolton, \& Drew, 1991; Cronin, 1994). However, there are a number of interesting avenues in the service area to be explored where exploration has not even begun.

Major advances in services management will only be made possible by means of a more integrated approach to conceptualizing and developing measurement scales for services. As a foundation for our research, we use Zeithaml's (1988) means-end chain approach, which suggests that before the final decision is taken, consumers analyze the information associated with a service using four different abstraction levels, ranging from simple attributes to complex personal values. Surprisingly, and although the intermediate levels have been extensively explored in the services management literature (particularly through the SERVQUAL scale), there is a clear research gap at the highest level. With this research, we expect to contribute to the services management literature by providing the SERPVAL scale, a new services scale at the personal value level.

When analyzing the personal values literature specifically, one notices an increase of research in this field in recent years. Personal values are beliefs or conceptions about end-goals or desirable end-states, classified by Rokeach (1973) as terminal values. They are key central 
elements in consumers' cognitive structure, meaning that by understanding and acting on consumer personal values, it may be possible to better understand consumer behavior. Personal values are a strong tool for understanding and reaching users and usages, as they can drive and explain consumer attitudes and behaviors.

Most recent research uses personal values to communicate the importance of products and services for consumers. More specifically, recent research focuses on finding key personal values behind different product contexts. To do so, quantitative and qualitative measurement scales have been built, looking for a better consumer understanding and enhancing the knowledge of products usage. Despite the need for research in personal values within service contexts, to our knowledge, there is not one study that looks into this phenomenon. Through the development of a broad personal values scale for services usage, we expect that this study will contribute to the furthering of knowledge on consumers' values towards services.

In sum, in this study we cross the literature on services management with research on personal values. The SERPVAL scale presented here allows the creation of a common ground for assessing service personal values, giving a clear understanding of the key value dimensions behind a service choice and usage. It will lead to a focus of future research in services management, extending knowledge in the field and stimulating further empirical research on service personal values. At the managerial level, the SERPVAL should allow practitioners to evaluate and improve the value of a service, and consequently, to define strategies and actions to address services for customers based on their fundamental personal values.

This article is organized into three sections. First, an overview of the current literature is offered. The conceptual framework is then tested via a field survey of more than 380 service 
users, and the four dimensions of the SERPVAL are presented. Implications for theory and managerial practice, limitations of the research, and future directions are also considered.

\section{THEORETICAL BACKGROUND}

\section{Four Levels to Assess Services}

According to Zeithaml's (1988) means-end chain approach to understanding the cognitive structure of consumers, product/service information is retained in memory at four levels of abstraction. This approach considers four different levels to assess a service: 1) in the lowest one we have the attribute level (simple service attributes), followed by 2) the quality level, 3) the value level, and finally, 4) the personal value level. This last level is more individual and complex than all of the other three.

At the first level, service attributes refer to functional benefits (Young, \& Feigin, 1975) or concrete service attributes (Olson, \& Reynolds, 1983). At the second level, a significant contribution was already given to the field of services management through the development of SERVQUAL and its constructs: Tangibles, Reliability, Responsiveness, Assurance and Empathy (Carr, 2002). Service quality is defined as the discrepancy between consumers' perceptions of services offered by a particular firm and their expectations about firms offering such services (Parasuraman, Zeithaml, \& Berry, 1988). It is a long-term attitude (Cronin, 1994), believed to affect behavioral intentions, which are thought to impact the consumer's individual behavior (Parasuraman, Zeithaml, \& Berry, 1996). At the third level, service value is another construct found in the literature, defined as a cognitive tradeoff between perceptions of quality and sacrifice (Cronin, 1994), or, as Zeithaml (1998) states, between the perception of what is received and given. 
Finally, at the fourth level we have service personal values. Although a scale is missing to assess personal values, these are considered to be better predictors of an individual's behavior (Madrigal, 1994) and more important than attitudes' influence on behavior (Durgee, 1996). As suggested by Zeithaml (1998), they can be more reliable and consistent in understanding consumer behavior towards a service than all of the other "lower level" constructs (at the attribute, quality and value levels).

In sum, Zeithaml's (1988) means -end chain approach explains hierarchically how an individual cognitively runs a consumer process. In a lower level, he pays attention to the product/service characteristics (as colors or guarantees). The quality level starts when he checks if all these perceptions are in accordance with the initial expectations he had of it. And if this level is successfully overcome, then the individual compares all the given product/service advantages with the sacrifices needed to have it. But in overall, the purchasing decision depends on service capacity to fulfill or show individuals' personal values; and that is why is so important to measure personal values.

\section{Measurement of Personal Values}

Values have been understood as intrinsic, lasting and relatively steady beliefs in an individual's life, defined as mental representations of needs, and used by individuals as a general base for conflict and decision resolution, determining, regulating and modifying relations between individuals, organizations and societies. "A value is an enduring belief that a specific mode of conduct or end-state of existence is personally or socially preferable to an opposite or converse mode of conduct or end-state of existence" (Rokeach, 1973: 5). According to Rokeach (1973) there are two types of values: the "object values" and the "individual values". Object values concern the value of an object, gained through a comparison with other objects, and 
translated into the amount paid when it is acquired. The second type has to do with the values owned by individuals. A deeper understanding of these values can lead to a better knowledge of object values (Zeithaml, 1988; Feather, 1995).

Personal values and their impact on consumer behavior have been deeply explored. One of the most powerful ways to understand and reach consumers is by understanding their values and systems of values (Durgee, 1996). Values are standards, from which beliefs, attitudes, and consequently, behaviors are formulated (Posner, 1987; Madrigal, 1994; Carlson, 2000). In this sense, individuals show their values and life styles through the acquisition of services (Kahle, 1988).

Personal values' selection and the way they are measured depend on the choice of model (Agle, \& Caldwell, 1999). Models exist where quantitative approaches are favored, springing from the principle that a specific set of personal values, established a priori, explains the individual's behavior towards a determined problem. Along this line are included, in a general perspective, the Rokeach Value Scale (RVS) (1973) and the List of Schwartz (1990); while, in a consumer analysis perspective, Vinson's Means-End Chain model (1977), Kahle's List of Values (LOV) (1983), Mitchell's Values and Lifestyles (VALS) topology (1983), Howard's Consumer Value Model (1989) and Durgee's List of Values (1996).

If an advantage resides in ease of problem approach and analysis, difficulties reside in two issues: first, choosing the suitable scale to use, and second, the inaccuracy resulting if the respondent is driven into a set of pre-determined values that cannot be perfectly related with the problem. The qualitative approach to measure values is the Means-End Chain model (Reynolds, \& Gutman, 1984) and respective interview method, Laddering, where the purpose is to find the hierarchy attribute-consequence-value behind a product choice. There are two main advantages 
to this model: the first is the way values are acquired, because, if they are mentioned by the consumer, it means that they are related with the subject of study; second, laddering prevents the quarrel around rankings or ratings. However, there still seems to be some doubt about the existence, or the validity, of this hierarchy in consumer mindsets (Bagozzi, 1999). The concerns regarding the scales and approaches above may not apply to the services field as, to our knowledge, none were constructed with services in mind.

\section{THE SERVICE PERSONAL VALUES CONSTRUCT}

Although service personal values may be found in research that explores individual values and their consequences for consumer behavior, there is no established operationalization of a SERPVAL scale. The inexistence of an established scale, duly adapted in order to understand and analyze personal values behind services usage, shows the need for a measurement scale with such a purpose. This need has to be rooted, however, in a conceptualization of the construct being scaled (Peter, 1981).

Service personal values can be defined as a customer's overall assessment of the use of a service based on the perception of what is achieved in terms of his own personal values. As consumer behaviors serve to show an individual's values (Kahle, 1988), the use of a service can also be a way to fulfill and demonstrate a consumer's personal values. In this sense, a service can provide more to the customer than its concrete and abstract attributes (Cohen, 1979; Gutman, \& Reynolds, 1979) or its functional consequences (Olson, \& Reynolds, 1983).

From both consumers' and practitioners' perspectives, values are extremely relevant, as they are desirable goals that serve as guiding principles in people's lives (Schwartz, 1992). While building on previous research (Rokeach, 1973; Kahle, 1983; Schwartz, 1990), we propose to assess service personal values through four broad groups of individual dimensions; at the self- 
oriented level we use 1) service value to living comfort, and 2) service value to peaceful life; at the social-oriented level we use 3) service value to social recognition, and 4) service value to social integration.

While building upon the RVS scale (Rokeach, 1973), a scale built specifically to assess general individual values; we develop the first two dimensions. The first dimension is the Service Value to Living Comfort (SVLC) meaning that a service has worth for the user if he/she recognizes that the service promotes a more comfortable life. Living comfort can be improved if the service brings ease to daily life, more freedom to act and helps to solve daily issues, affording its user a way of avoiding or rapidly overcoming possible life adversities. Service Value to Peaceful Life (SVPL) is our second dimension. If a service promotes a pleasurable life, brings or improves tranquility, safety and/or harmony, then its user recognizes the value of this service. Generally, this service can improve the user's pleasure of life, since it protects or defends the consumer from threats or pressures to life.

While building upon both the LOV scale (Kahle, 1983), a scale built specifically to assess consumer values, and the RVS scale (Rokeach, 1973) for individual values, we develop the other two dimensions: Service Value to Social Recognition (SVSR) and Service Value to Social Integration (SVSI). The roles of social recognition and social integration to improve service personal value have been seriously neglected. Social recognition derives its outcome utility from its predictive utility (Bandura, 1986). When applying this underlying belief to our third dimension, Service Value to Social Recognition (SVSR), we assume that people use a service while taking into consideration the content of what is delivered (Stajkovic, \& Luthans, 2002). Individuals consider whether the service aids in gaining respect from others, social recognition 
and status, as well as whether it allows achieving a more fulfilled and stimulating life, which might then be revealed to others.

People also tend to engage in behavior that receives social recognition and avoid behavior that leads to social disapproval (Bandura, 1986; Luthans, \& Stajkovic, 2000), and this contributes to an individual's social integration. This leads us to the fourth dimension, Service Value to Social Integration (SVSI), which is based on the fact that if the consumer perceives that a service strengthens friendships, provides the possibility of becoming more integrated in the group, or promotes better relationships at the social, professional or family levels, then the service will contribute to social integration, and naturally the individual will recognize personal value in the service.

To sum up, since consumers will determine their future behavior on the basis of the degree of social recognition and social integration provided by a service (Bandura, 1986, 1997; Stajkovic, \& Luthans, 1998), in today's highly dynamic markets, service firms will have to be aware of personal perceptions of both service dimensions in order to survive and gain competitive advantage.

\section{METHOD}

\section{The Research Setting}

The research setting was in a European country (Portugal) in the telecommunications service - more specifically, in the mobile services market. The most recent data show that this country has increased its own mobile market exponentially. The mobile communications market carries over $80 \%$ penetration and people are becoming ever-greater users of mobile services; especially those related with messaging, location, information and entertainment. There are high expectations for the future, given that Portugal is now one of the leading countries in terms of 
conditions and potentialities in the mobile services market (International Telecommunications Union, 2002). In an era when communications are fundamental for a country's development, research in this particular field is essential.

\section{Survey Instrument Development}

We developed a measurement scale to capture service personal values. In order to develop our survey instrument in an early stage, we used previously established scales (Rokeach, 1973; Kahle, 1983; Schwartz, 1990). We adapted these scales to fit within the services domain context. Hence, in the following stage, we adapted some of the established scales to today's services reality, using as a basis a comprehensive qualitative method (focus group and interviews). This stage also revealed new items and key dimensions, which helped us in defining the meaning of service personal values. This work was complemented by a questionnaire developed in Portuguese.

In our study we use a seven-point Likert scale, ranging from "1- strongly disagree" to "7strongly agree", to assess the initial 28 items. Controversy exists in the literature regarding existing scales, and advantages and disadvantages are appointed to both rankings and ratings, or to combined solutions (Hicks, 1970; Becker, 1998; Meglino, \& Ravlin, 1998). Our final choice of the seven-point Likert scale was based on research purposes and characteristics: to obtain differences (instead of orders) between values, as the dimensions are not mutually exclusive; to obtain reliable results, which could be compromised if users were asked to rank all of the 28 options.

Two judges assessed the survey instrument's content and face validity. After revisions, a pretest sample of thirty mobile service users was used. A full listing of the 16 final items after 
purification and their scale reliabilities is included in appendix. The average internal reliability (Cronbach alpha) was .87. The excluded items are also found in appendix.

\section{Data Collection Procedure}

The data were collected in 2001. A convenience sample of 386 individuals was employed. Similarly to Cavusgil, \& Zou (1994), data were gathered through in-depth personal interviews with mobile services users. Personal interviews enabled open-ended responses of mobile services usage and helped to ensure that the chosen respondents use these services. It was also believed that the data collected through in-depth personal interviews yielded higher response rates than a mail survey would have. In order to ensure that the respondents had significant knowledge about mobile services, we used Marktest data in order to identify an appropriate sampling frame.

\section{CONFIRMATORY FACTOR ANALYSIS}

In order to assess the validity of the measures, the items were subjected to a confirmatory factor analysis (CFA), using full-information maximum likelihood (FIML) estimation procedures in LISREL 8.3 (Jöreskog, \& Sörbom, 1993). In this model, each item is restricted to load on its pre-specified factor, with the four first-order factors allowed to correlate freely. The chi-square for this model is significant $\left(\chi^{2}=396.28,98 \mathrm{df}, \mathrm{p}<.00\right)$. Since the chi-square statistic is sensitive to sample size, we also assessed additional fit indices: the Standardized Root Mean Square Residual (RMSR), Comparative Fit Index (CFI), the Incremental Fit Index (IFI), and the TuckerLewis Fit Index (TLI). The RMSR, CFI, IFI, and TLI of this model are .05, .91, .92 and .90 respectively (see Table 1). Convergent validity is evidenced by the large and significant standardized loadings of each item on its intended construct (average loading size was .73). Discriminant validity among the constructs is stringently assessed using the Fornell, \& Larcker 
(1981) test; all possible pairs of constructs passed this test. Figure 1 presents the standardized coefficients and $\mathrm{t}$-values for this measurement model.

Second-order factor. Figure 2 presents the estimation results for the final measurement model of SERPVAL. Specifically, a higher order SERPVALUE factor that includes four first-order factors, observable indicators and measurement errors is estimated. The SVLC factor has a factor loading on the higher order factor of .88, SVPL has a factor loading of .94, SVSR of .74, and finally SVSI has a loading of .90 on the higher order factor. The t-values are also shown in Figure 2. Although the chi-square of 1417.75 is significant $(\mathrm{df}=679, \mathrm{p}<.00)$, the fit indices suggest a good fit of the model to the data $(\mathrm{RMSR}=.05, \mathrm{CFI}=.91, \mathrm{IFI}=.91, \mathrm{TLI}=.90)$. As we may observe in Table 1, these fits are extremely similar to the measurement model with four factors correlated. Thus, our proposed second-order model is supported, as it is equivalent to the first-order model. What this means is that consumers assess services according to four basic dimensions of personal values, and in addition, supports the view that SERPVAL has a high order factor, and that SERPVAL has 4 basic dimensions with sub-dimensions associated with them in the consumer's mind (Dabholkar, Thorpe, \& Rentz, 1996).

\section{DISCUSSION}

\section{Theoretical Implications}

The highest portion of research in business values deals with individual values (Agle, \& Caldwell, 1999). However, to our knowledge, not one study has dealt with assessing overall personal values as well as their dimensions in a service context. Similar to previous research in the field (e.g., Kettinger \& Lee, 1994), considerable indicator deletions had to be made in order to reach acceptable levels of model fit in the full structural model (see Appendix A). Our final results show that all the scales adapted from the Schwartz list (1990) were excluded. A possible 
explanation is that although Schwartz builds on Rokeach's (1973) work in order to explore individual values (Steekamp, Hofstede, \& Wedel, 1999), its dimensions might be especially focused on analyzing societal values (Agle, \& Caldwell, 1999). As we are looking for individual dimensions, this might explain why the values inspired by the Schwartz list were excluded from the model.

The hierarchical structure of the scale presented in this paper also presents theoretical implications. Although we cannot claim to definitively capture the dimensions of service personal values, we believe that we come closer to capturing these overall evaluations because the second-order factor extracts the underlying commonality among dimensions. In addition to obtaining respondents' evaluations of the dimensions, the second-order factor model captures the common variance among these dimensions, reflecting the respondents' overall assessment of service personal values.

Towards this fact, we expect that the service personal values conceptualization and measurement scale presented here contribute to both business values literature and the service management field, allowing for the delineation of strategies for adding value to services. The selection of a strategy for a particular service depends on its customers' personal values. Being highly customer-oriented means having a strong commitment to customers, trying to create customer value, and understanding customer needs (Narver, \& Slater, 1990). Enhancing service distinctiveness in order to improve living comfort, provide a peaceful life, increase social recognition, and gain a better social integration, are all possible strategies that companies may pursue, but the one(s) to pursue depends on the outstanding personal values held by the service customers. 


\section{Contributions to Practice}

This new scale also presents managerial implications. Managerial assessment of the personal values of a service might be extremely important because it allows managers to better understand what customers want or value. Thus, it allows us to identify what services are really valuable to the final consumer; providing knowledge for making choices about which services to include. Traditional approaches have focused attention on service attributes (as quality) and service consequences (as service value), but personal values may be an important set of variables to be considered in understanding what attracts consumers to a certain service. By knowing the dimensions a consumer takes into account when choosing a service, a better understanding of purchasing behaviors may be realized, guiding managers into customers' expectations.

The examination of performance might be improved because managers can discuss the relationship between service personal values and performance. The SERPVAL dimensions give some guidance on how to better pursue a highly service- oriented business strategy. The SERPVAL scale can also be used for benchmarking purposes, as this scale can be used to identify whether or not a firms' marketing strategies are consistent with consumers' expectations. Finally, this research has implications for consumers as well. As more companies seek to build relationships with their customers, consumers are easily able to examine whether these relationships provide real value or not to their own lives.

\section{Limitations and Directions for Future Research}

There are some limitations of the research to be considered. The first limitation is that the final survey instrument (i.e. the questionnaire) may have created common method variance that could have inflated construct relationships. This could be particularly threatening if the respondents were aware of the conceptual framework of interest. However, they were not told 
the specific purpose of the study, and all of the construct items were separated and mixed so that no respondent would be able to detect which items were affecting which factors. Hence, it is expected that the biasing possibilities of common method variance were minimized (Lages, \& Jap 2002).

Second, a problem typically associated with SERVQUAL/SERVPERF scales, is that generalization from a single sample presents limitations (Kettinger, \& Lee, 1995; Carr, 2002). Although the fit indices suggest a good fit of the model to the data, future research is encouraged to test our instrument across different services settings. Some studies which have tested the SERVQUAL scale in pure service settings (Carman, 1990), banking (Spreng, \& Singh, 1993), and different types of retail stores (Finn, \& Lamb, 1991) suggested that the SERVQUAL scale should be modified to different settings. It is worthwhile to study, for example, the SERPVAL scale within a medical service context; would the same scale items hold together as well as they do in the current research? Similarly, the SERPVAL scale should also be applied in other countries. The research context involved only one country, which may limit the generalizability of the results to some degree. Although countries in situations similar to that of Portugal may benefit from the findings, to establish its generalizability, multiple samples in different market contexts are needed.

Future research is also suggested to focus on the stability of this measure. Even though personal values are relatively stable, value systems of individuals may be subject to change (Brangule-Vlagsma, Pieters, \& Wedel, 2002). Furthermore, research is needed to explore the linkages among attribute level, quality level, value level and personal value level. Research is particularly required when analyzing the antecedents and consequences of service personal values. For example, it is suggested to investigate how the service personal values construct is 
related to well established constructs in this field, such as customer loyalty, customer satisfaction or customer performance. The service personal values construct may also give better knowledge to further positioning and communicating services. Could service personal values be related to advertising messages or could advertising messages seek to assess specific service personal values as a way to differentiate the provider in the marketplace?

Finally, continued refinement of the SERPVAL scale proposed in this study is certainly possible based on further qualitative and quantitative research. We encourage researchers to add the items which were excluded in a latter stage from the final scale (see Appendix A), as well as to add new items and factors applicable to the research setting.

In sum, the SERPVAL research instrument was developed in this paper. Instead of treating SERPVAL as a unidimensional construct, various measurement units for each of the four constructs were presented. SERPVAL is presented as a second-order model with a secondorder construct (SERPVALUE) and four first-order constructs: Service Personal Value to Living Comfort (SVLC), Service Personal Value to Peaceful Life (SVPL), Service Personal Value to Social Recognition (SVSR) and Service Personal Value to Social Integration (SVSI). Through the development of the SERPVAL scale we expect to contribute to both business values and service management literatures. At a time when marketing researchers are challenged to provide research with practical implications, it is believed that managers may use this measurement scale to pursue service-oriented business strategies while taking into consideration what customers value. 


\section{REFERENCES}

Agle, Bradley \& Caldwell, Craig (1999). Understanding research on values in business. Business and Society, 38(3), 326-387.

Bagozzi, Richard P. (1999). Goal setting and goal striving in consumer behavior. Journal of Marketing 63: 19-32.

Bandura, A. (1986). Social foundations of thought and action. Englewood Cliffs. NJ: PrenticeHall.

Bandura, A. (1997). Self-efficacy: The exercise of control. New York: Freeman

Becker, Boris W. (1998). Values in advertising research: A methodological caveat. Journal of Advertising Research, 38(4), 57-60.

Bolton, Ruth N. \& Drew, James H. (1991). A multistage model of customers' assessments of service quality and value. Journal of Consumer Research, 17(Mar), 375-384.

Brady, Michael K., Cronin, Joseph Jr. (2001). Some new thoughts on conceptualizing perceived service quality: A hierarchical approach. Journal of Marketing, 65(Jul), 34-49.

Brangule-Vlagsma, Kristine, Pieters, Rik \& Wedel, Michel (2002). The dynamics of value segments: Modeling framework and empirical illustration. International Journal of Research in Marketing, 19(3), $267-285$.

Carlson, D. (2000). Work family conflict in the organization: Do life role values make a difference? Journal of Management, 26(5), 1031-1054.

Carman, James M. (1990). Consumer perceptions of service quality: An assessment of the SERVQUAL dimensions. Journal of Retailing, 66(Spr), 33-55.

Carr, Christopher L. (2002). A psychometric evaluation of the expectations, perceptions, and difference-scores generated by the IS-Adapted SERVQUAL instrument. Decision Sciences, 33(2), 281-296.

Cavusgil, S. T. \& Zou, S. (1994). Marketing strategy-performance relationship: An investigation of the empirical link in export market ventures. Journal of Marketing, 58(1), 1-21.

Cohen, J. (1979). The structure of product attributes: Defining attribute dimensions for planning and evaluation. In Analytic Approaches to Product and Marketing Planning. A. Shocker Ed., Cambridge. MA: Marketing Science Institute.

Cronin, J. Joseph, Taylor, Steven A. (1994). SERVPERF versus SERVQUAL: Reconciling performance-based and perceptions-minus-expectations measurement of service quality. Journal of Marketing, 58(Jan), 125-131.

Cronin, J. Joseph, Brady, Michael K., Brand, Richard R., Hightower, Roscoe Jr. \& Shemwell, Donald J. (1994). A cross-sectional test of the effect and conceptualization of service value. The Journal of Services Marketing, 11(6), 375.

Dabholkar, Pratibha A., Thorpe, Dayle I. \& Rentz, Joseph O. (1996). A measure of service quality for retails stores: Scale development and validation. Journal of the Academy of Marketing Science, 24(1), 3-16.

Durgee, Jeffrey F. (1996). Translating values in product wants. Journal of Advertising Research, 36(6), 90-100. 
Feather, N. T. (1995). Values, valences and choices: The influence of values on the perceived attractiveness and choice of alternatives. Journal of Personality and Social Psychology, 68: 1135-1151.

Finn, David W. \& Lamb, Charles W. (1991). An evaluation of the SERVQUAL Scales in a retailing setting. In R. Holman and M.R. Solomon (Ed.), Advances in Consumer Research. 483-490. Provo. UT: Association for Consumer Research.

Gutman, J. \& Reynolds T. (1979). An investigation of the levels of cognitive abstraction utilized by consumers in product differentiation. In J. Eeighmey (Ed.), Attitude research under the sun. Chicago: American Marketing Association.

Hicks, L.E. (1970). Some properties of ipsative, normative, and forced-choice normative measures. Psychological Bulletin, 74: 167-187.

ITU- International Telecommunications Union (2002). Internet for a mobile generation. ITU Q3 - 2002 Report, Eurostat.

Jöreskog, Karl G., Sörbom, Dag (1993). LISREL 8: Structural equation modeling with the SIMPLIS command language. Hillsdale NJ: Lawrence Erlbaum Associates.

Kahle, L. (1983). Dialecting tensions in the theory of social values. In L. R. Kahle (Ed.), Social issues and social change: Adaptation to life in America. 275-84. New Yorker: Praeger.

Kahle, L. (1988). Using the list of values LOV to understand consumers. The Journal of Services Marketing, 2(3), 49-57.

Kettinger, W. J. \& Lee, C. C. (1994). Perceived service quality and user satisfaction with the information services function. Decision Sciences, 25(5), 737-766.

Kettinger, W. J. \& Lee, C. C. (1995). Global measurements of information systems service quality: A cross-national study. Decision Sciences, 25(5), 737-766.

Lages, Luis Filipe \& Jap, Sandy D. (2002), A contingency approach to marketing mix adaptation and performance in international marketing relationships. Working Paper $n r .411$, Lisbon, Portugal: Faculdade de Economia, Universidade Nova de Lisboa.

Luthans, Fred, Stajkovic, Alexander D. (2000). Provide recognition for performance improvement. In E. A. Locke. (Ed.), Principles of Organizational Behavior. 166-180. Oxford. England: Blackwell.

Madrigal, R. \& Kahle, L. (1994). Predicting vacation activity preferences on the basis of valuesystem segmentation Journal of Travel Research, 32(4), 22-32.

Meglino, Bruce M., Ravlin, Elizabeth C. (1998). Individual values in organizations: Concepts. controversies, and research. Journal of Management, 24(3). 351-389.

Narver, John C. \& Slater, Stanley F. (1990). The effect of a marketing orientation on business profitability. Journal of Marketing, 54(Oct), 20-35.

Olson, J. \& Reynolds, T. (1983). Understanding consumers' cognitive structures: Implications for advertising strategy. In L. Percy and A. Woodside (Ed.), Advertising and Consumer Psycho logy. Lexington. MA: Lexington Books.

Parasuraman, A., Zeithaml, V. \& Berry, L. (1985). A conceptual model of service quality and its implications for future research. Journal of Marketing, 49(Fall), 41-50.

Parasuraman, A., Zeithaml, V. \& Berry, L. (1988). SERVQUAL: A multiple-item scale for measuring consumer perceptions of service quality. Journal of Retailing, 64(1), 12-40. 
Parasuraman, A., Zeithaml, V. \& Berry, L. (1991). Refinement and reassessment of the SERVQUAL scale. Journal of Retailing, 67(4). 420-450.

Parasuraman, A., Zeithaml, V. \& Berry, L. (1994). Reassessment of expectations as a comparison standard in measuring service quality: Implications for further research. Journal of Marketing, 58(Jan), 111-124.

Parasuraman, A., Zeithaml, V. \& Berry, L. (1996). The behavioral consequences of service quality. Journal of Marketing, 60(Apr), 31-46.

Peter, J. Paul. (1981). Construct Validity: A review of basic issues and marketing practices. Journal of Marketing Research, 18(May), 133-45.

Posner, B., Randolph, W. \& Schmidt, W. (1987). Managerial values across functions: A source of organizational problems. Group and Organization Studies, 12(4), 373-385.

Reynolds, Thomas J. \& Gutman, Jonathan (1984). Advertising is image management. Journal of Advertising Research 24(1), 27-37.

Rokeach, M.J. (1973). The nature of human values. New York: The Free Press.

Spreng, Richard A. \& Singh, A. K. (1983). An empirical assessment of the SERVQUAL scale and the relationship between service quality and satisfaction. In David W. Cravens and Peter Dickson (Ed.), Enhancing knowledge development in marketing, 1-6. Chicago: American Marketing Association.

Schwartz, S. H. (1990). Toward a theory of the universal content and structure of values: Extensions and cross-cultural repications. Journal of Personality and Social Psychology, 58: 878-91.

Schwartz, S. H. (1992). Universals in the content and structure of values: Theoretical advances and empirical tests in 20 countries. In M. Azzna (Ed.) Advances in Experimental Social Psychology. Boston. MA: Academic Press.

Stajkovic, Alexander D. \& Luthans, Fred (1988). Social cognitive theory and self-efficacy: Going beyond traditional motivational and behavioral approaches. Organizational Dynamics, 26(4), 62-74.

Stajkovic, Alexander D. \& Luthans, Fred (2001). Differential effects of incentive motivators on work performance. Academy of Management Journal, 44(3), 580-590.

Steekamp, Jan-Benedict, Hofstede, Frenkel ter \& Wedel, M. A (1999). Cross-national investigation into the individual and national cultural antecedents of consumer innovativeness. Journal of Marketing, 63(2), 55-69.

Young, Shirley \& Feigin, Barbara (1975). Using the benefit chain for improved strategy formulation. Journal of Marketing, 39(Jul), 72-4

Zeithaml, V. (1988). Consumer perceptions of price, quality and value: A means-end synthesis of evidence. Journal of Marketing, 52(3), 2-22. 
Figure 1: SERPVAL Scale: First-Order Model

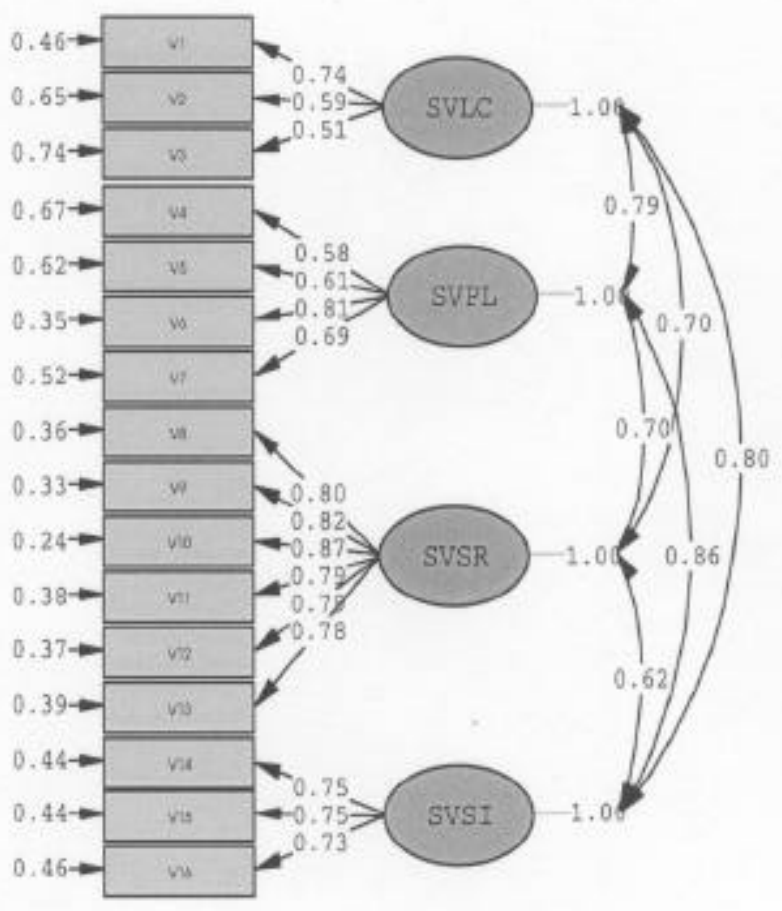

Standardized Coefficients

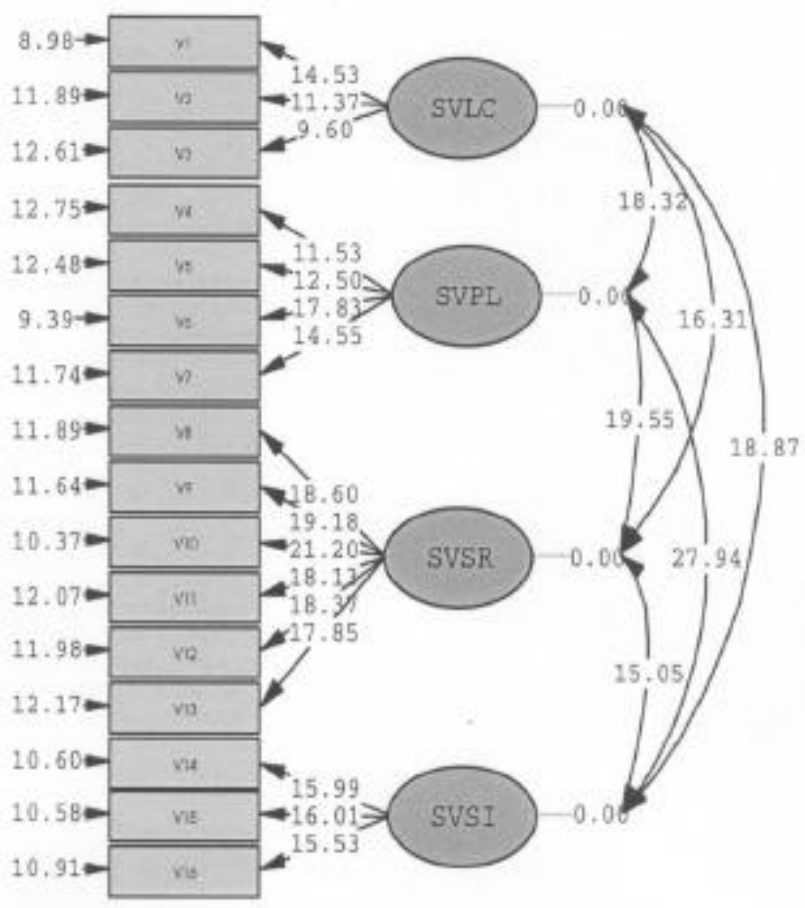

T-Values

Figure 2: SERPVAL Scale: Second-Order Model

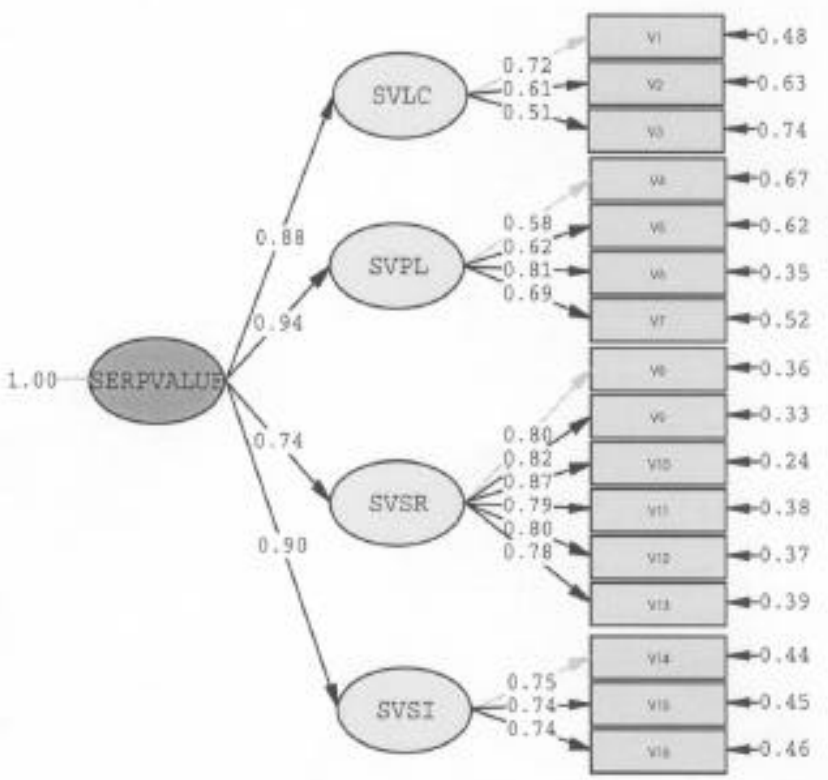

Standardized Coefficients

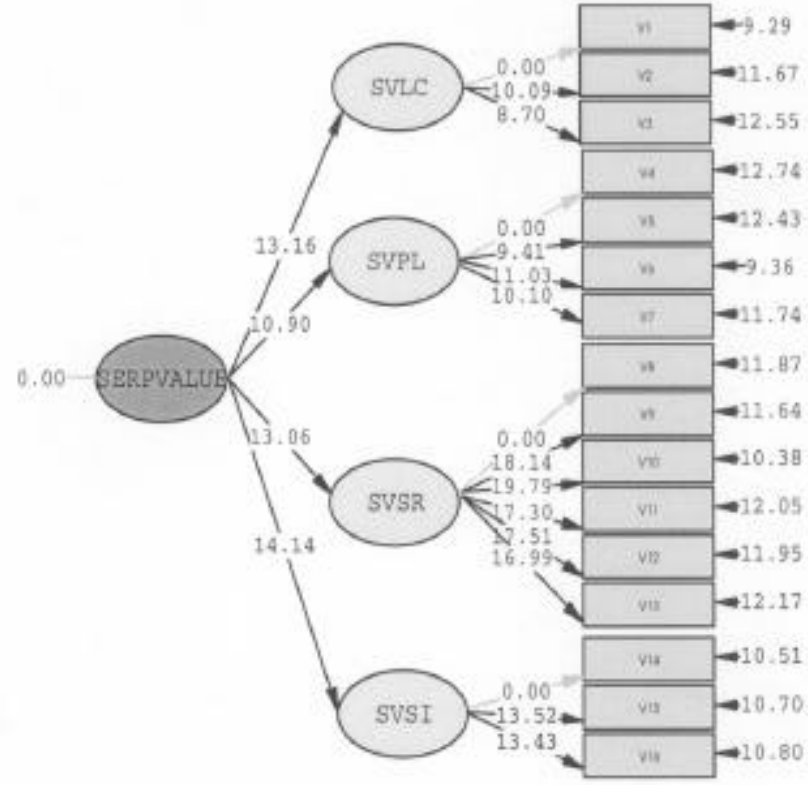

T-Values

Table 1: Structural Equation Results

$\begin{array}{llllllll}\text { Model } & 2 & \text { df } & ? 2 / \mathrm{df} & \text { RMSR } & \text { CFI } & \text { IFI } & \text { TLI }\end{array}$

$\begin{array}{llllllllll}\mathrm{M}(0) & \text { One factor } & 1244.92 & 104 & 11.97 & .09 & .77 & .77 & .75\end{array}$

$\begin{array}{llllllll}\text { M(1) } 4 \text { factors correlated } & 396.28 & 98 & 4.04 & .05 & .91 & .92 & .90\end{array}$

$\begin{array}{llllllll}\text { M(2) Second-order factor } & 404.05 & 100 & 4.04 & .05 & .91 & .91 & .90\end{array}$




\section{Constructs, Scale Items and Reliabilities}

Adapted from

The use of mobile services allows me to achieve ...

(1-Strongly Disagree to 7- Strongly Agree)

SVLC- Service Personal Value to Living Comfort $(\alpha=0,88)$

V1 ...more comfort in my life

Rokeach (1973)

V2 ...more freedom to act

Rokeach (1973)

V3 ...a better communication with others

Rokeach (1973)

SVPL- Service Personal Value to Peaceful Life $(\alpha=0,94)$

$\begin{array}{ll}\text { V4 } & \text {...more tranquility } \\ \text { V5 } & \text {..more family security } \\ \text { V6 } & \text {...more harmony } \\ \text { V7 } & \text {.... more pleasurable life }\end{array}$

Rokeach (1973)

Rokeach (1973)

Rokeach (1973)

Rokeach (1973)

SVSR- Service Personal Value to Social Recognition $(\alpha=0,74)$

V8 $\quad$... more respect from others

Kahle (1983)

V9 ... more enthusiasm in daily life

Rokeach (1973)

V10 ... the feeling that the world is more agreeable

Rokeach (1973)

V11 ... more social recognition

Rokeach (1973)

V12 ... more status

V13 ... a more stimulating and adventurous life

Rokeach (1973)

Rokeach (1973)

SVSI- Service Personal Value to Social Integration $(\alpha=0,90)$

V14 ... a higher integration in my group

Kahle (1983)

V15 ... better relationships (e.g. social, professional and family)

Kahle (1983)

V16

... stronger friendship relationships

Rokeach (1973)

The items below were excluded:

Adapted from

The use of mobile services allows me to achieve ...

(1- Strongly Disagree to 7- Strongly Agree)

- $\quad$... the feeling that the world is more pleasant

Rokeach (1973)

... the feeling that more equality exists

Rokeach (1973)

... more success

- $\quad$... more power to influence others

Schwartz (1990)

Schwartz (1990)

... more self-esteem

Rokeach (1973)

- $\quad$... more knowledge

- $\quad$... more personal and professional fulfillment

Rokeach (1973)

... more national security

Rokeach (1973)

Rokeach (1973)

- $\quad$... more fun

Kahle (1983)

... more conditions to help others

Schwartz (1990)

... more balance in my emotional life

Rokeach (1973)

... more latitude in decision-making

Schwartz (1990) 